\title{
Occurrence of Puccinia spp. spores in Madeira Island and their phytopathological importance
}

\author{
Irene Camacho • Rubina Leça • Duarte Sardinha • \\ Roberto Camacho • Magdalena Sadyś
}

Accepted: 1 September 2017 / Published online: 19 September 2017

(C) Koninklijke Nederlandse Planteziektenkundige Vereniging 2017

\begin{abstract}
The genus Puccinia represents rust infections, which are responsible for great productivity losses in crops of commercial and ornamental plants worldwide. This work is aimed at determining the occurrence of Puccinia spp. spores in Madeira Island in order to infer the exposure risks from a phytopathological point of view. A phytopathological analysis was performed in 203 local plant samples between January 2003 and December 2012. During the same period the airborne concentrations of rust spores were monitored following well-established guidelines. Aerobiological data was compared with meteorological records. Based on macro and microscopic analyses, five species of rusts were identified: P. horiana, P. buxi, P. porri, P. pelargonii-
\end{abstract}

I. Camacho $(\bowtie) \cdot$ R. Camacho

Faculty of Life Sciences, Madeira University, Campus

Universitário da Penteada, 9000-390 Funchal, Portugal

e-mail: camire@uma.pt

R. Camacho

e-mail: roberto_camacho2000@hotmail.com

R. Leça · D. Sardinha

Laboratório de Qualidade Agrícola da Camacha, Caminho

Municipal dos Caboucos, $n^{\circ}$ 61, 9135-372, Camacha, Portugal

R. Leça

e-mail: rubinafilipa@gov-madeira.pt

D. Sardinha

e-mail: duartesardinha@gov-madeira.pt

M. Sadyś

Rothamsted Research, West Common, Harpenden AL5 2JQ, UK

e-mail: magdalena.sadys@ rothamsted.ac.uk zonalis, and P. sorghi, and they were found mostly in spring and summer. A total of 20 samples out of 203 analysed plants (9.8\%), were infected with Puccinia spores, i.e., P. horiana (5.9\%), P. buxi (1.47\%), $P$. porri and $P$. pelargonii-zonalis $(0.98 \%)$, and P. sorghi (0.5\%). During the studied period Puccinia spores attained an annual average concentration of 126 spores $\mathrm{m}^{-3}$ and most of them were recorded between March and October. Meteorological factors were determinant in fluctuations in spore concentration. Relative humidity was the parameter that favoured the biggest release and dispersal of the rust spores, whereas rainfall revealed a significant negative effect. Rusts do not represent an important plant pathogen in Madeira Island, as shown by the low infection frequencies and levels of airborne spore concentrations.

Keywords Rust · Inoculum detection · Infection conditions · Aerobiology $\cdot$ Portugal

\section{Introduction}

Puccinia are fungi which cause the plant diseases commonly known as rusts. They belong to the Pucciniales order (formerly called Uredinales), which represents one of the largest group of Basidiomycetes (Hiratsuka and Sato 1982; Morris et al. 2013). Rusts constitute a diverse group of plant pathogens with over 120 genera and 6000 species (De Wolf et al. 2011). They have complex life stages that include the production of sexual spores (basidiospores) and up to four functionally and 
morphologically different asexual spores which assure dissemination and winter survival (Morris et al. 2013). In addition to such different number of spore stages, they often need two unrelated groups of host plants to complete their life cycles, but some can complete it on only one kind of host plant. Hosts of rust fungi range from ferns and gymnosperms to highly evolved families of Dicotyledons such as Leguminosae, Euphorbiaceae, and Monocotyledons such as Liliaceae and Orchidaceae (Hiratsuka and Sato 1982). They frequently occur on grasses and seeds of several vegetable species (Farr et al. 1989).

Rusts are produced in unquantified quantities and are aerodynamically ultra-light reaching long distances in short periods of time (Roelfs 1985; Morris et al. 2013). Rust spores also possess thick walls and pigmentation that protect them against UV radiation and can remain viable while transported over long distances (Agrios 1997). Soybean rust is one of the most destructive foliar diseases of soybean caused by the rust Phakopsora pachyrhizi which has the ability to spread rapidly over large geographic areas provoking serious effects on crops. Its spread was monitored over a decade since 1995, moving swiftly from South America to the United States (Isard et al. 2005).

During the crop season numerous microscopic spores, mostly asexual urediniospores, ensure long distance dissemination of the fungi. The beginning of the epidemic spread of rusts depends mostly on rainfall, when the primary inoculum composed by airborne spores is deposited on the host plants (Nagarajan and Singh 1990). It has been demonstrated that the spring and early summer ensures the most propitious environmental conditions for spore production. During this period, unquantified quantities of spores are ready to be discharged from the host plants and being transported up to thousands of kilometres, until they reach other suitable host plants (Roelfs 1985; Morris et al. 2013). When infection is advanced, the plant surface becomes reddish/brown because of the powdery urediniospore masses (Russi et al. 2009). Severe levels of disease can halt growth or even destroy the plants by causing water and nutrient losses through restriction of the photosynthetic area (Marasas et al. 2004).

Several species of Puccinia have historical and economic importance worldwide: $P$. triticina, a leaf rust that causes wheat disease (Roelfs 1985), P. graminis a stem rust, and the stripe rust caused by $P$. striiformis. $P$. psidii is another rust fungus with a wide and expanding host range within the Myrtaceae family, with over 440 host species currently known (Morin et al. 2012; Pegg et al. 2014). In addition, P. melanocephala brown rust is an important sugarcane disease that is responsible for large yield losses worldwide (Peixoto-Junior et al. 2014), $P$. arachidis infects groundnut (Mallaiah and Rao 1982) and P. penniseti was also described as an important cereal crop pathogen (Kadam et al. 2010).

Besides the phytopathological importance, rust spores can also play an important role in the pathogenesis of allergic diseases (Ho et al. 1995; Guarín et al. 2015). In general, basidiospores along with ascospores are among the predominant airborne primary biological aerosol particles in atmospheric surveys (RiveraMariani and Bolanños-Rosero 2012). The volume of many ascospores and basidiospores in the atmosphere and their small size can allow them to reach deep into the respiratory tract system (Levetin and Horner 2002). These features play an important role in respiratory allergies and induce a wide range of symptoms, including allergic rhinitis and asthma (D'Amato and Spieksma 1995). Puccinia is one of the genera associated with the allergenic processes whose spores have been detected in the atmosphere of temperate and tropical regions: Hungary (Magyar and Manninger 2004), Spain (Trejo et al. 2013), India (Ghatge et al. 2013), Colombia (Guarín et al. 2015) and UK (Sadyś et al. 2016). These aerobiological studies aimed to assess the time of rust spore occurrence in the atmosphere and the environmental conditions that influence spore dispersion and infection. In fact, aerobiological monitoring of fungal spores can provide an efficient forecasting system for a high variety of crops which are affected by fungal diseases (Jędryczka et al. 2012).

In Madeira, several surveys were completed to detect phytopathogenic fungi in vegetables and ornamental crops over the years in order to find the main diseases caused by fungi. The first description of rust occurrence in the island was published in 1830 by Holl (1830), followed by several other reports in the early 1900s, in the years 1937, 1947 and 1980 (Gjaerum 1982). Later on, Talhinhas et al. (2016) described rust symptoms in Canna $\times$ hybrida plants at a garden in Funchal caused by $P$. thaliae. In addition, rust symptoms were observed on daylily plants in gardens at Funchal city (Silva et al. 2016).

The island presents mild temperatures throughout the year which combined with high humidity rates are 
favourable conditions for the cultivation of different crops, mainly tropical, subtropical and temperate fruits, vegetables and ornamentals both outdoor, and indoors. Given the economic importance and the widespread distribution of rust spores, this study aimed at determining the occurrence of Puccinia spp. spores in Madeira Island in order to infer the exposure risks from a phytopathological point of view.

\section{Materials and methods}

Site description

The study took place in Madeira Island (Portugal) between January 2003 and December 2012. Madeira is a volcanic island located $900 \mathrm{~km}$ southwest of Portugal and $600 \mathrm{~km}$ west of the western African coast (Fig. 1). It has a surface area of $739 \mathrm{~km}^{2}$ and $58 \mathrm{~km}$ by $23 \mathrm{~km}$ range. Madeira Island is within the Macaronesian biogeographical region, presenting a temperate hyperoceanic sub-Mediterranean bioclimate (RivasMartínez 2001), with mild temperatures all year round $\left(18.7^{\circ} \mathrm{C}\right.$ on average), relative humidity varying between $55 \%$ and $75 \%$, and rainfall range from $500 \mathrm{~mm}$ to $1000 \mathrm{~mm}$ (Quintal 2007).

Nearly two-thirds of Madeira Archipelago territory is a national park with a unique endemic flora and fauna. Its key habitat is the laurisilva forest which contains a wide array of plant species, including abundant endemic bushes, bryophytes, lichens, mosses and liverwort species (Borges et al. 2008). The mild subtropical climate enables the coexistence of a noticeable variety of tropical and subtropical plants, representing a suitable substrate for fungal growth and reproduction (Quintal 2007; Borges et al. 2008).

\section{Phytopathological analysis}

The phytopathological analysis of infected plant material (stems, leaves) was performed between January 2003 and December 2012. The samples were taken by farmers from different locations in Madeira, namely: Calheta, Câmara de Lobos, Funchal, Ponta do Sol and Santa Cruz (Fig. 2). Since Puccinia spp. (hereafter Puccinia) spores are obligate parasites, the collected plant specimens were subjected to the wet chamber technique. As such, we used previously sterilized petri dishes containing sterile paper filter and absorbent cotton wetted with sterilized distilled water in order to maintain the humidity conditions inside the plates. A plastic grid previously disinfected with alcohol was placed between the material under investigation and the paper filter and cotton wool wetted in order to avoid direct contact. The infected material was placed on the plastic grid with tweezers and the wet chambers were sealed with parafilm and identified. To avoid condensation inside the incubation chambers, they were placed

Fig. 1 Location of Madeira Island (the scale is relative to the mainland territory)

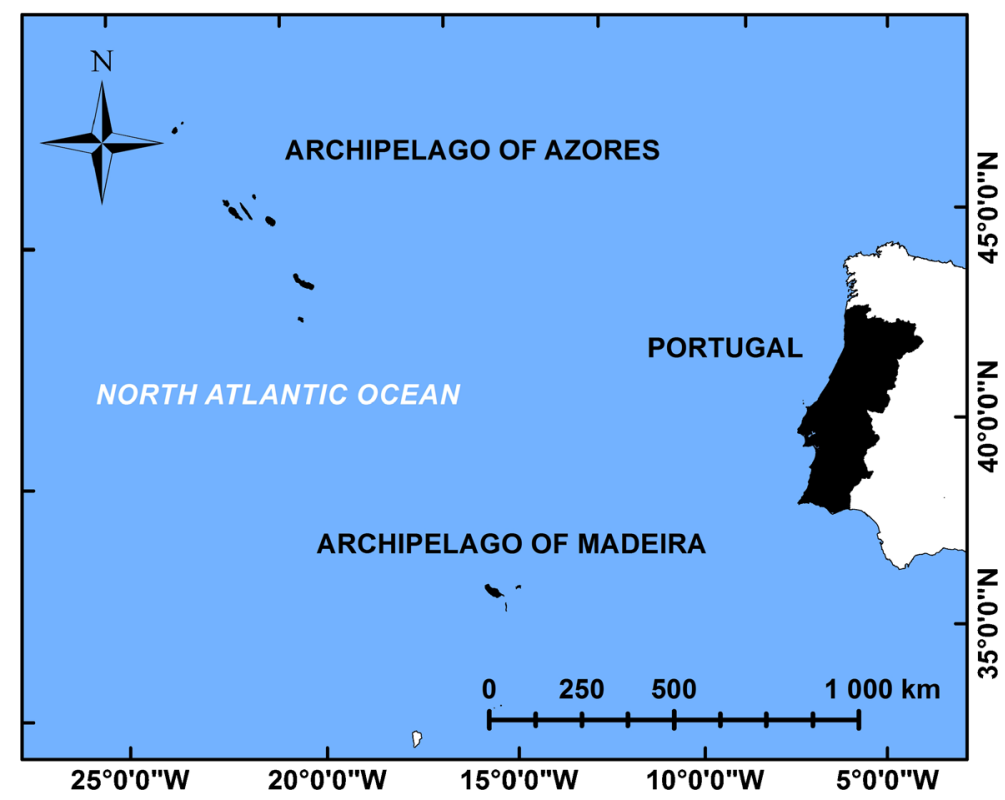




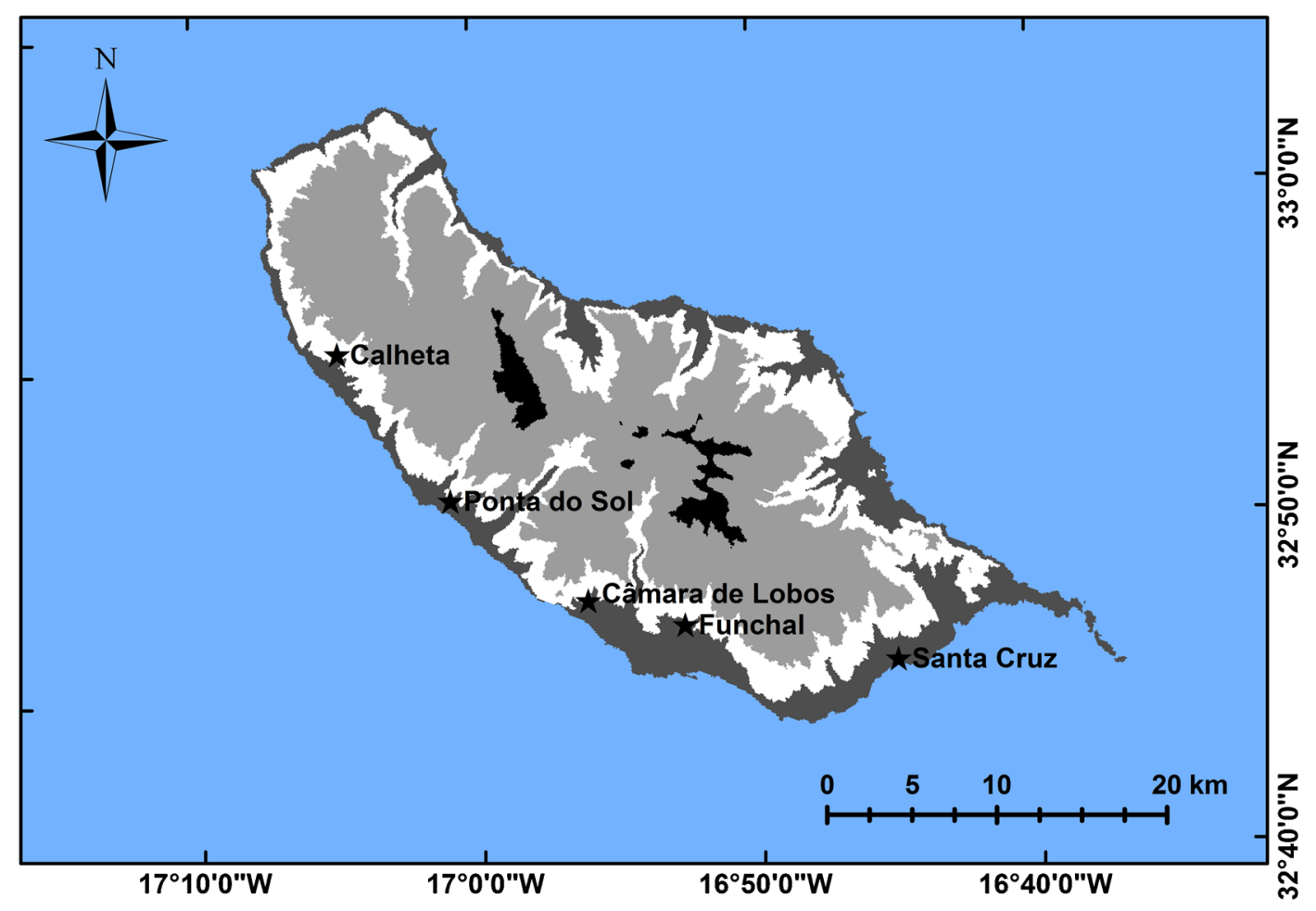

\section{The topography of the Madeira Island [m a.s.I.]}

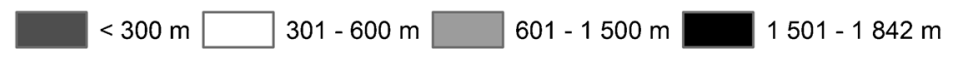

Fig. 2 Sites where the plant samples were taken for mycological analysis

on a laboratory bench, out of direct light and at room temperature. The wet chambers were observed periodically in order to check the growth of the mycelium and / or the fruit bodies. The identification of Puccinia isolates was done with the help of a stereo microscope (Nikon SMZ-U) and an optical microscope (Nikon Model Eclipse E-600). Using a stereo microscope, a portion of mycelium was removed from infected tissues with a sterilized needle, mounted in a glass slide with a drop of lactophenol Cotton Blue (Merck) and examined under the optical microscope. A total of 25 teliospores and 25 urediniospores from each plant specimen were microscopically examined and measured. The spores images from $P$. horiana, $P$. pelargonii-zonalis, and $P$. sorghi were captured digitally using an Olympus DP-11 digital camera attached to the optical microscope. However, not all Puccinia spores were captured digitally, and for that reason the images of spores from $P$. porri, $P$. buxi and $P$. sorghi were obtained, after permission, from forestry images website of the Center for Invasive Species and Ecosystem Health, USA (https://www.forestryimages.org/search/). Photographs of garlic leaves infected with $P$. porri and maize leaves infected with $P$. sorghi were also provided by the aforementioned website.

\section{Aerobiological monitoring}

Airborne fungal spores were collected by Hirst type volumetric trap (Burkard Manufacturing Co. Ltd., UK) (Hirst 1952) located on the roof of the Dr. João de Almada Hospital in Funchal city, about $10 \mathrm{~m}$ above ground level. Air monitoring and analysis were performed according to the methods described by the Spanish Aerobiology Network (Galán et al. 2007) and the Minimum Recommendations proposed by the European Aerobiology Society Working Group on Quality Control (Galán et al. 2014).

The volumetric trap is equipped with a vacuum pump that draws $10 \mathrm{~L}$ of air per minute. The impacting particles are trapped on a Melinex tape coated with silicone solution (Lanzoni) placed on a clockwork-driven drum moving at $2 \mathrm{~mm} \mathrm{~h}^{-1}$. The 
Melinex tape is replaced weekly, cut into seven portions corresponding to a 24-h sampling (48 mm each), and mounted on microscope slides. Each portion is stained with glycerine gel (Merck) containing fuchsin (Lanzoni s.r.l., Italy). The identification and counting of fungal spores was performed using a light microscope (Olympus BX50) at magnification $\times 400$ on four longitudinal transects along the slides. The airborne fungal spore concentration was calculated and expressed as number of fungal spores per cubic metre of air (spores $\mathrm{m}^{-3}$ ).

The Hirst trap was not operating for a 2-month period (Jan-Feb 2006) due to a mechanical failure.

Meteorological variables of air temperature (mean, max and min), relative humidity, rainfall, wind direction and wind speed were provided by the Institute of Ocean and Atmosphere (IPMA) - Regional Station in Funchal. The IPMA is located approximately $5 \mathrm{~km}$ South-East of the sampling site.

\section{Statistical analysis}

Due to non-linearity and non-normality of the analysed variables, Spearman's rank correlation analysis was applied in order to examine the relationships between Puccinia spore concentration in the air and weather parameters. The calculations were made based on the daily average concentration of the airborne particles and daily mean values of the weather data. Statistical analysis was carried out using SPSS 17.0 and GenStat 18.0 programmes.

\section{Results}

Identification of fungal isolates

During the study period 203 plant samples were analyzed which included grasses, horticultural and ornamental plants (Table 1). Based on the characteristics of spores and plant symptoms, the pathogens causing rust in plant samples were identified. A total of 20 out of 203 analysed samples (9.8\%), were infected with Puccinia: 12 samples $(5.90 \%)$ were diagnosed with $P$. horiana, 3 (1.47\%) were infected with P. buxi, $2(0.98 \%)$ with P. porri, $2(0.98 \%)$ with P. pelargonii-zonalis, and 1 $(0.5 \%)$ with $P$. sorghi.

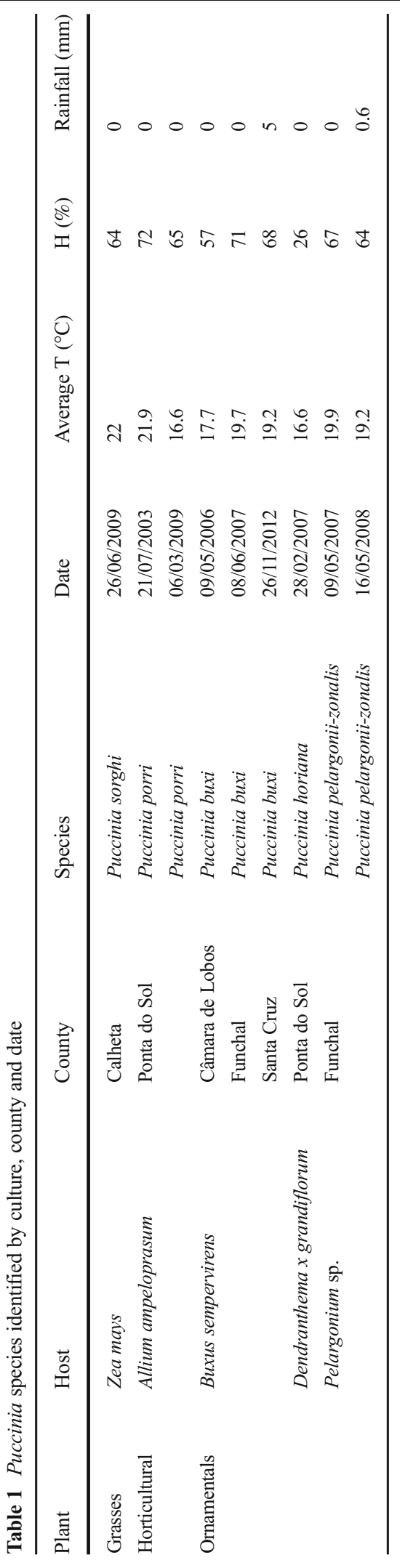



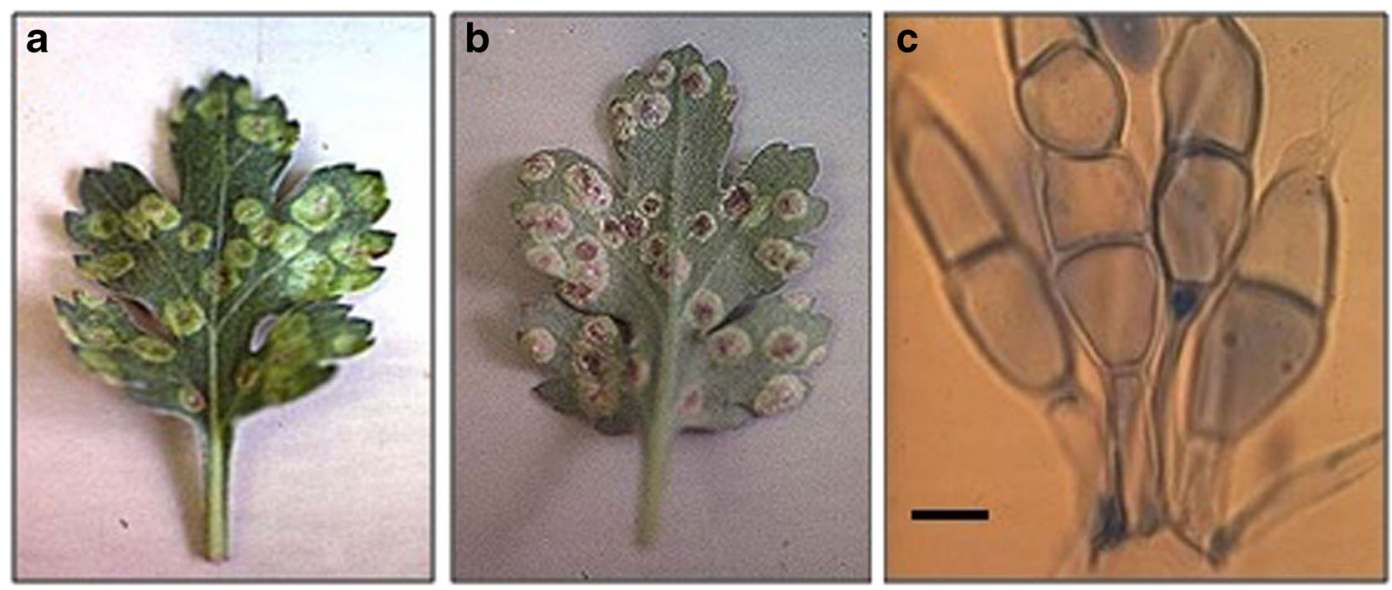

Fig. 3 Chrysanthemum leaves with small yellow spots to light brown on the upper side (a) and powdery pustules white-pink colour on the underside, in the corresponding areas of these spots (b), caused by the P. horiana. (c) Teliospores of $P$. horiana $(100 \times)$. (scale: $10 \mu \mathrm{m})$

\section{Morphological descriptions}

Plants with $P$. horiana revealed leaves with small yellow to light brown spots. On the underside, in areas corresponding to the spots of the upper page, it was noticeable white-pinkish pustules with a floury aspect (Fig. 3 a-b). In Chrysanthemum, two types of spores were observed, the teliospores (Fig. $3 \mathrm{c}$ ) and the basidiospores. Microscopic examination of the pustules revealed subhyaline cylindrical or clavate teliospores, rounded apex, 2-celled, slightly constricted at the septum, $30-46 \times 12-18 \mu \mathrm{m}$, with pedicels persistent up to $45 \mu \mathrm{m}$ long.

Plants infected with $P$. pelargonii-zonalis, showed greenish-yellow circular spots on both sides of the leaves. In the center of these spots, small whitish pustules appeared that released a powdery mass of brown-blackish spores (urediniospores). On the underside of leaves the pustules were arranged in concentric circles (Fig. 4 a-b). The teliospores appeared mixed with urediniospores (Fig. 4 c). Teliospores were pale brown, ellipsoid or clavate, 54.5$64.5 \times 20-30 \mu \mathrm{m}$, upper cell darker than lower cell, constricted at the septum, pedicel hyaline, persistent, up to $40 \times 7 \mu \mathrm{m}$. Urediniospores were yellowishbrown broadly globose or subglobose, $22-32 \times 19-$ $25 \mu \mathrm{m}$, pedicels $45 \mu \mathrm{m}$ long.

In plants infected with $P$. porri, the fungus was observed in the leaves along the veins, revealing small orange-coloured pustules which later become brown (Fig. 5 a). The urediniospores were observed in the sorus of light orange colour. Teliospores were oblong shape, measured 55-58 $\times 15-22 \mu \mathrm{m}$, pedicels no longer than $15 \mu \mathrm{m}$ (Fig. 5 b).

Infected plants with $P$. buxi revealed irregular orange patches on the leaves with a dark brown and powdery aspect (Fig. 6 a). Teliospores were yellow-brown oblongate, $55-82 \times 20-25 \mu \mathrm{m}$, with very long pedicels (Fig. 6 b).

Plants infected with P. sorghi showed circular to elongated light brown to dark brown pustules detectable on both sides of the leaf. (Fig. 7 a). Microscopic observations of the fungus spores revealed dark brown oblong to ellipsoid teliospores, rounded at the apex and base, constricted at the septum, 18-23 × 30-45 $\mu \mathrm{m}$. Urediniospores were light brown ovoides, $23-27 \times 27-$ $32 \mu \mathrm{m}$, pedicels varying between $18 \mu \mathrm{m}$ long on average (Fig. 7 b-c).

\section{Aerobiological data of Puccinia spores}

During the studied period a total 60,944 fungal spores and 15 genera were identified in the atmosphere of Funchal, Madeira Island. Cladosporium was the most abundant fungal spore type with $38.2 \%$ of the total fungal spectrum, followed by Botrytis and Ascospores, whereas Stemphylium were the least frequent (1.6\%). Puccinia accounted for $3.7 \%$ of the total fungal spore spectrum (Table 2).

The total of Puccinia spores varied between 11 and 549 spores $\mathrm{m}^{-3}$ of air, with the highest values being registered in 2009 and the lowest in 2003 (Table 3; Fig. 8). On average, these species occur in the atmosphere on 46 days (13\%) throughout the year, mostly in 


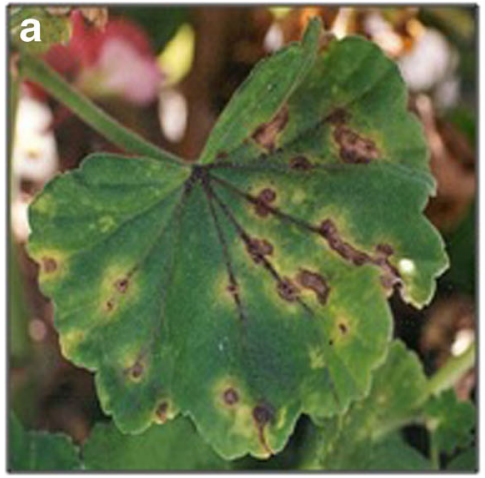

Fig. 4 Mallow leaves with yellow-green circular spots on the upper side (a) and pustules with powdery masses of brown-blackish spores arranged in concentric circles on the underside (b),

March and October, attaining an annual daily mean concentration of 126 spores $\mathrm{m}^{-3}$. The peak concentration occurred in February (2004), in March (2011), in April (2010), in September (2006), in October (2007, $2008,2009,2012)$ and also in November (2005).

When meteorological data was analysed, during the study period the temperatures increased in Funchal from March to September, declining between October and February (Fig. 9). The prevailing weather conditions recorded revealed an average temperature of $19.8{ }^{\circ} \mathrm{C}$, maximum and minimum temperatures of 23.4 and 17.3 ${ }^{\circ} \mathrm{C}$, respectively. The relative humidity was higher during the hottest period of the year, characterized by the absence of rain. The relative humidity recorded an average value of $64.1 \%$, and precipitation reached $1.8 \mathrm{~mm}$ on average. In regards to wind conditions, the prevailing wind was coming from the South-West with an average speed of $1.72 \mathrm{~m} \mathrm{~s}^{-1}\left(6.2 \mathrm{~km} \mathrm{~h}^{-1}\right)$. caused by $P$. pelargonii-zonalis. (c) $P$. pelargonii-zonalis spores. Teliospores elongated, and rounded urediniospores $(100 \times)$. (scale: $50 \mu \mathrm{m})$

The results from the correlation analysis between Puccinia spore concentrations and meteorological parameters are shown in Table 4. These spores presented a statistically significant positive and negative (depending on the year examined) correlation with air temperature (mean, maximum, minimum), relative humidity, wind direction and wind speed. There was a statistically significant relationship between Puccinia spore concentration and wind direction in 2006 and 2011. In the first year increased levels of spores were detected when the wind blew from the SW direction, while in the second year the same was observed when the wind originated from the NE direction. A strict statistically significant negative correlation was found with rainfall. In three out of 10 years under investigation, no statistically significant relationship between Puccinia occurrence and all weather parameters $(2003,2007$, and 2010) was found. An examination of a 10 -year period revealed

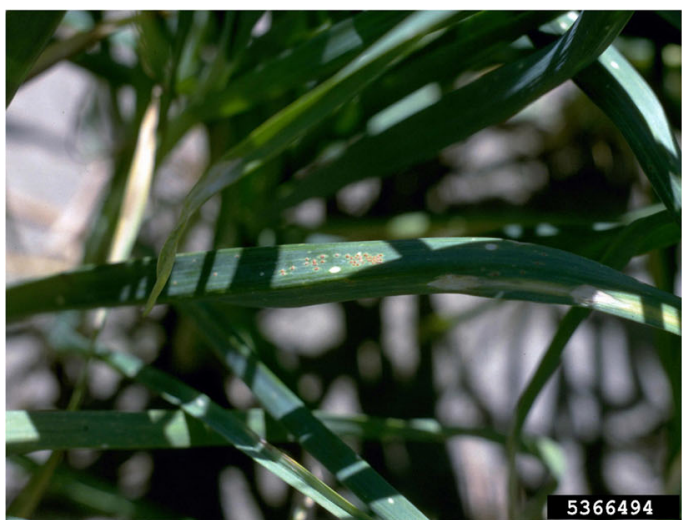

Fig. 5 Leaves of garlic, with small orange-coloured pustules which later become brown along the veins (from Howard F. Schwartz, Colorado State University, Bugwood.org) (a).

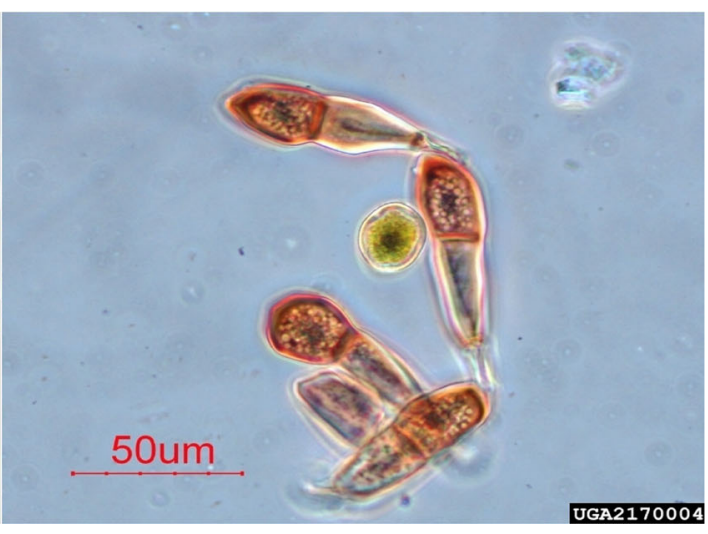

Urediniospores and teliospores of fungi Puccinia porri (b) (from Cesar Calderon, USDA APHIS PPQ, Bugwood.org) 
Fig. 6 Leaves of $B$. sempervirens with yellows spots and with brown and powdery pustules (a). P. buxi spores $(40 \times)(\mathbf{b})$. (scale: $50 \mu \mathrm{m})$
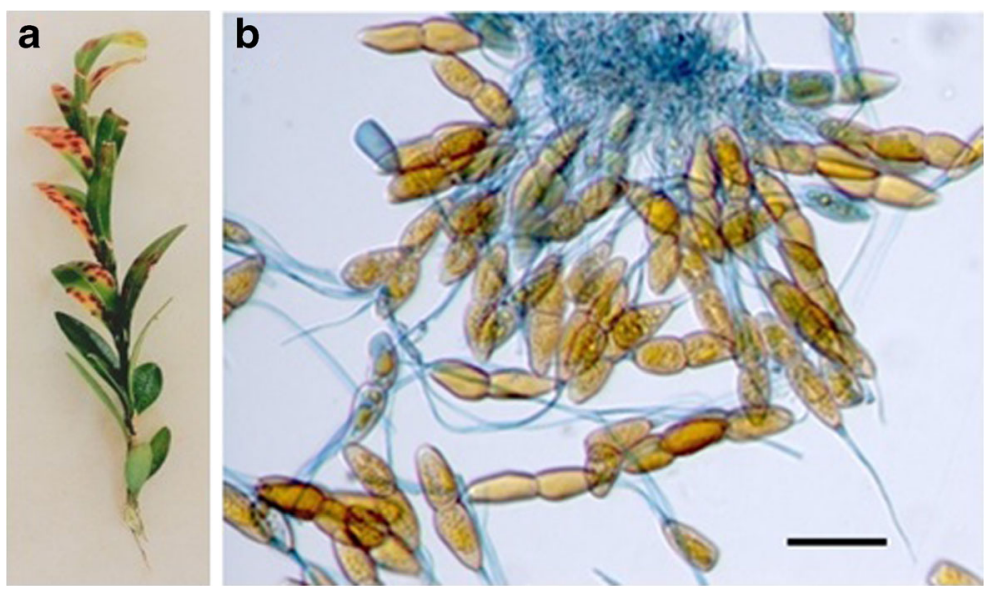

dependence of Puccinia spores only on the fluctuations of relative humidity $\left(r_{s}=0.047, p<0.05\right)$.

\section{Discussion}

Several rust species have been described as having phytopathological importance worldwide. Currently, they are considered as invasive species, whose lifecycle and infection process are well documented. Basically, rusts utilize the atmosphere as a dispersion pathway in order to ensure successful long movements and reach potential hosts (Isard et al. 2005). Nowadays, aerobiological monitoring is an additional tool that can predict and anticipate these types of invasions on crops and ornamental plants.

In the present work, five species of Puccinia were identified on grasses, horticultural and ornamental plants. Despite the low number of occurrences on host plants, the morphological identifications took place during the most favourable time of the year for rust infection, between spring and summer (Table 1). The spore stages may cycle until the overwintering stage presumably expressed as teliospores which are replaced by uredinia and telia in higher temperatures. The capability shown by some pathogens to survive between different seasons, or even to colonize new areas represents an important survival strategy as a result of long distance dispersal by wind currents (Gage et al. 1999).

The common rust caused by $P$. sorghi is normally found in the summer, a feature also observed in Madeira Island. In tropical and subtropical regions where maize is grown throughout the year, the pathogen reproduces on successive crops by means of a repeating uredinial stage. In areas where maize is grown principally as a summer crop, the pathogen can overwinter as teliospores (Dunhin et al. 2004). In the atmosphere of Mérida (SW Spain) Trejo et al. (2013) observed the maximum values of Puccinia spores in summer and

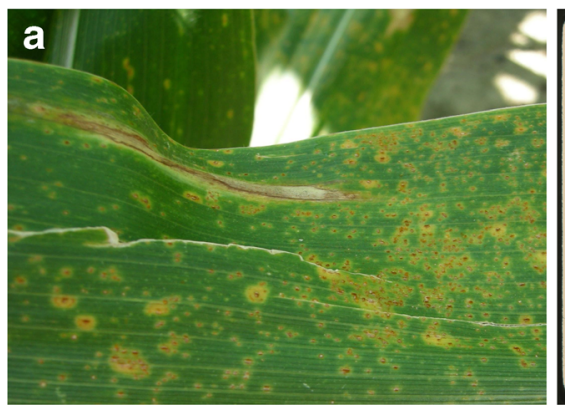

Fig. 7 Leaf of Zea spp. showing light brown pustules (Larry Osborne, Bugwood.org) (a). Spores of of P. sorghi. Urediniospores (b) and teliospores (c) (Penn State Department of
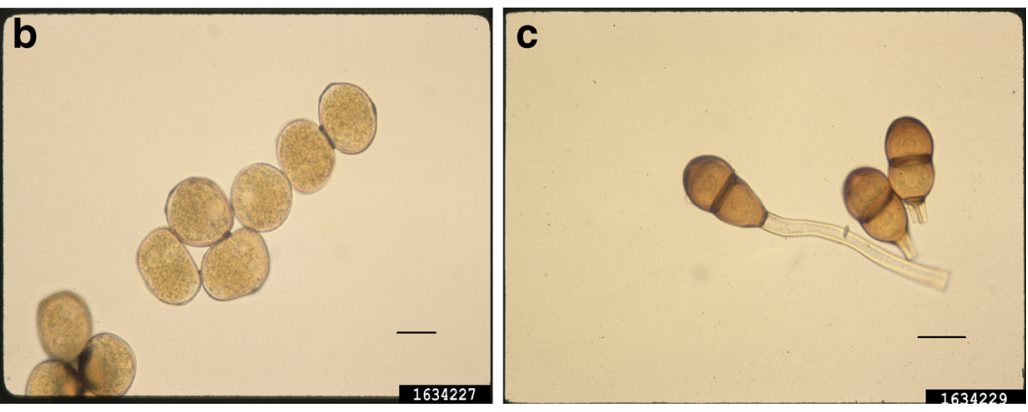

Plant Pathology \& Environmental Microbiology Archives, Penn State University, Bugwood.org). (scale: $10 \mu \mathrm{m}$ ) 
Table 2 Prevalent fungal spores recorded in the atmosphere of Funchal region during the studied period

\begin{tabular}{lll}
\hline Fungal spore type & Annual totals (2003-2012) & Contribution \% \\
\hline Cladosporium & $23,256,17$ & 38,2 \\
Botrytis & 5818,83 & 9,5 \\
Ascosporos & 5015,52 & 8,2 \\
Leptosphaeria & 3145,46 & 5,2 \\
Ganoderma & 3044,62 & 5,0 \\
Agaricus & 2851,99 & 4,7 \\
Fusarium & 2439,96 & 4,0 \\
Coprinus & 2315,48 & 3,8 \\
Puccinia & 2238,3 & 3,7 \\
Arthrinium & 1579,54 & 2,6 \\
Alternaria & 1467,94 & 2,4 \\
Venturia & 1135,8 & 1,9 \\
Torula & 1099,44 & 1,8 \\
Stemphylium & 989,27 & 1,6 \\
Other & 4545,3 & 7,5 \\
Total & 60,944 & 100,0 \\
\hline
\end{tabular}

lower occurrences in spring and autumn. In contrast, a number of reports of $P$. psidii showed peak times during warmer wetter months of summer and the drier winter months in Queensland, Australia (Pegg et al. 2014).

A total of 12 plant samples (5.9\%) were diagnosed with $P$. horiana, responsible for the white chrysanthemum rust. It is an autoecious microcyclic pathogen producing two spore types (Bonde et al. 2014), referenced by the European and Mediterranean Plant Protection Organization (EPPO/CABI 1997) as a quarantine fungus. Disease symptoms were observed on the leaves, but other authors observed typical infection symptoms on various parts of Chrysanthemum plant (Göre 2008). P. horiana originates in Japan and has spread to other far Eastern countries, to South Africa, and from there to Europe. The long-distance dispersal stated in P. horiana on a continental scale was also reported in other rust spores (Purdy et al. 1985; Nagarajan and Singh 1990; Kolmer 2001).

White rust established in most western European countries (Zadoks 1967; EPPO/CABI 1997; Fried et al. 2017). Given the increasing international importance of Chrysanthemum and the decreasing availability of registered fungicides in some regions, breeding programs to sort resistance to a relevant set of pathotypes is becoming more important (De Backer et al. 2011).

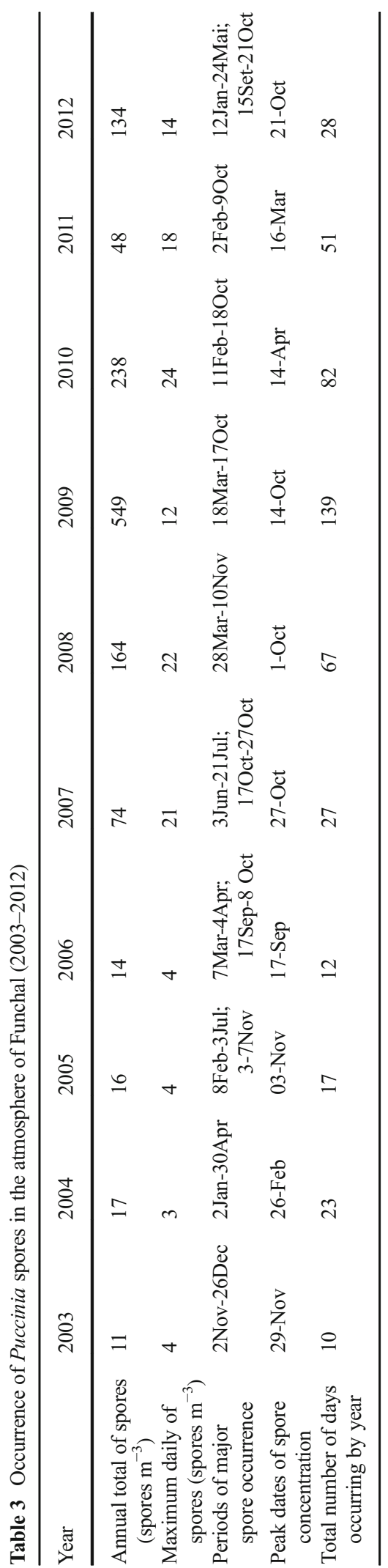




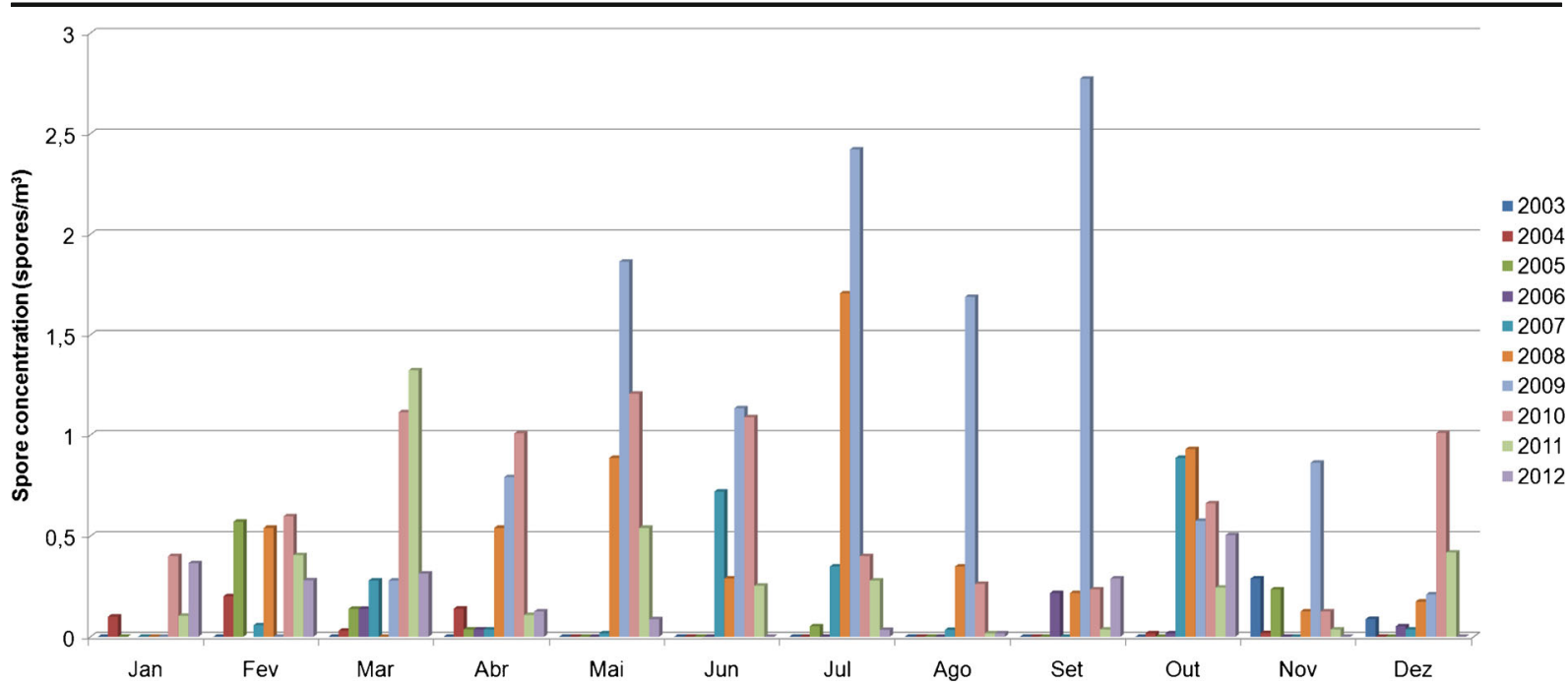

Fig. 8 Total monthly concentration of Puccinia in the atmosphere of Funchal, Madeira Island (2003-2012)

In Madeira, this particular rust type appeared during winter (average temperature $16.6{ }^{\circ} \mathrm{C}$ and $26 \%$ relative humidity). According to EPPO/CABI (1997), the bicellular teliospores germinate in situ to produce unicellular basidiospores which are dispersed in air currents. Teliospore germination and discharge of basidiospores occur between $4{ }^{\circ} \mathrm{C}$ and $23{ }^{\circ} \mathrm{C}$, at the optimum temperature of $17^{\circ} \mathrm{C}$, which is in accordance with our observations. In turn, high humidity appears to be necessary for the germination of both teliospores and basidiospores (EPPO/CABI 1997), but it has been shown that teliospores survive a maximum of 8 weeks at $50 \%$ relative humidity, and less time at higher humidity levels (Bonde et al. 2014).
P. pelargonii-zonalis responsible for the rust-ofmauve disease has a narrow host range and is considered an obligate parasite (Scocco et al. 2013). The genus Pelargonium is a popular greenhouse plant worldwide. This fungus occurred only in Funchal during the spring under favourable climatic conditions (around $19^{\circ} \mathrm{C}$ and $64-67 \%$ of relative humidity). The first record of this species in Madeira is from 1973 namely in Funchal, Santa Cruz, and Curral das Freiras (Câmara de Lobos municipality) (Gjaerum 1982). The rust fungus on geranium became a serious pathogen, particularly in North temperate greenhouses. Originally recorded in South Africa, it has been found in several other countries, and throughout Europe (Hutchidon 1996). Reports of

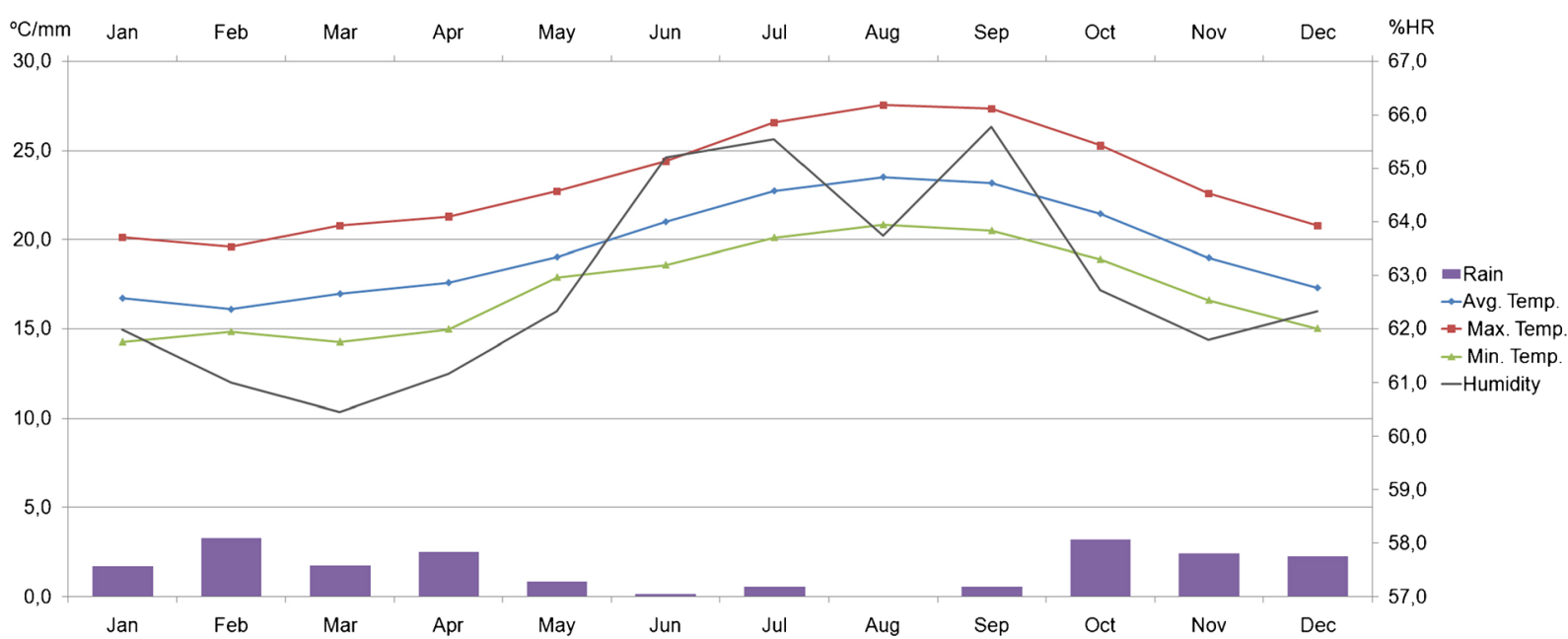

Fig. 9 Prevailing weather conditions recorded during the study period (2003-2012) in Funchal city: minimum, average and maximum temperature, relative humidity and rainfall 
Table 4 Spearman rank correlation coefficients between Puccinia spore concentration in the air and weather parameters (2003-2012). Results that achieved a statistical significance of $p<0.05$; were highlighted in bold and marked with an asterisk

\begin{tabular}{|c|c|c|c|c|c|c|c|}
\hline Year & $\begin{array}{l}\text { Temperature } \\
\text { mean }\end{array}$ & $\begin{array}{l}\text { Temperature } \\
\text { maximum }\end{array}$ & $\begin{array}{l}\text { Temperature } \\
\text { minimum }\end{array}$ & $\begin{array}{l}\text { Relative } \\
\text { humidity }\end{array}$ & Rainfall & $\begin{array}{l}\text { Wind } \\
\text { direction }\end{array}$ & $\begin{array}{l}\text { Wind } \\
\text { speed }\end{array}$ \\
\hline 2003 & -0.044 & -0.078 & -0.030 & 0.062 & -0.051 & -0.015 & 0.003 \\
\hline 2004 & $-0.240 *$ & $-0.203 *$ & $-0.256^{*}$ & -0.001 & 0.033 & 0.003 & $0.049 *$ \\
\hline 2005 & $-0.102 *$ & $-0.116^{*}$ & -0.079 & -0.183 & -0.090 & -0.016 & $0.140 *$ \\
\hline 2006 & -0.071 & -0.052 & -0.077 & 0.083 & -0.094 & $0.131 *$ & 0.008 \\
\hline 2007 & 0.020 & -0.007 & 0.042 & 0.080 & -0.041 & -0.053 & 0.030 \\
\hline 2008 & $0.214 *$ & $0.208 *$ & $0.224 *$ & 0.070 & 0.027 & -0.023 & 0.012 \\
\hline 2009 & $0.332 *$ & $0.296 *$ & $0.339 *$ & 0.053 & $-0.164 *$ & 0.069 & -0.036 \\
\hline 2010 & 0.030 & 0.031 & 0.039 & 0.054 & -0.031 & 0.008 & 0.066 \\
\hline 2011 & $-0.166^{*}$ & $-0.154 *$ & $-0.169 *$ & $-0.135^{*}$ & 0.060 & $-0.111 *$ & 0.052 \\
\hline 2012 & $-0.114^{*}$ & -0.095 & $-0.135^{*}$ & -0.050 & -0.048 & -0.024 & -0.027 \\
\hline $\begin{array}{c}2003- \\
12\end{array}$ & 0.026 & 0.017 & 0.030 & $0.047 *$ & -0.025 & -0.016 & 0.031 \\
\hline
\end{tabular}

this rust disease were also described by Hutchidon (1996) in Ontario, Canada, by Göre (2008) in Turkey and in Michoacán, Mexico (Gregorio-Cipriano et al. 2013). These observations also support the evidence of long long-distance transport of plant pathogens, as discussed earlier to $P$. horiana. The invasive potential of such pathogens relies on its ability to use atmospheric pathways for rapid spread into new areas and on the local appearance of new diseases in sites where they were previously unknown (Isard et al. 2005).

Puccinia porri is a fungus responsible for garlic rust. It was detected in Allium ampeloprasum in Ponta de Sol municipality (SW Madeira), under temperatures around $19{ }^{\circ} \mathrm{C}$, relative humidity conditions higher than $60 \%$, and absence of rain. Ponta de Sol is characterized as having a mild warm climate. The temperature records on average $18.7^{\circ} \mathrm{C}$ and precipitation reaches $577 \mathrm{~mm}$ annually. Typically, May, June, July and August correspond to the driest periods whereas November to January are the wetter ones. According to other findings, this fungus survives from one season to another, in spontaneous Allium species. It is favoured by high relative humidity (97\%), weak rainfall and mild temperature (between $10{ }^{\circ} \mathrm{C}$ and $24^{\circ} \mathrm{C}$ ). The optimum development temperature is $18{ }^{\circ} \mathrm{C}$, a condition observed in Ponta do Sol where P. porri was found. The risk of infection increases by dense plantings, vigorous growth due to excess of nitrogen and lack of potassium in the soil (Pria et al. 2008). There are descriptions of leek rust caused by this particular species in the UK during warm damp conditions (Harrison 1987). In the summer of 2014, the presence of $P$. porri on stem samples of Allium vineale was confirmed in York (UK) (Sansford et al. 2015).

Puccinia buxi usually attacks boxwood plants (Buxus sempervirens). It was detected in Funchal and in municipalities nearby during spring and autumn. In fact, the fungus grows during the summer and fall and for that reason the infection zones in the leaves become thicker. This disease is boxwood specific and there are no alternative hosts (RHS 2016). Previous reports of this rust have been done by Gjaerum (1982) in Funchal and Ribeiro Frio (Santana municipality) and in 1986 by Dennis (1986). Preece (2000) found that P. buxi only occurred on old large box trees and bushes, apparently not spreading to young plants. According to the author, this rust type is being conserved at old sites because of lack of disturbance of old trees and bushes bearing the fungus.

In our survey, Puccinia sorghi was found in a Zea mays host from Calheta (SW Madeira), a municipality where the cereal crops are of great importance (Calheta 2017). The rust infection was reported during the summer, at $22{ }^{\circ} \mathrm{C}$ and $64 \%$ of relative humidity. It is known as the fungus that causes the corn rust disease. The favourable conditions for the development of $P$. sorghi are temperatures between 16 and $18.3{ }^{\circ} \mathrm{C}$ to $23-23.8^{\circ} \mathrm{C}$ and high relative air humidities (Babadoost 1991; Zanatta 2013), conditions that are in accordance with our findings. Common rust was previously reported in 
United States (Babadoost 1991) and in South Africa (Dunhin et al. 2004) in maize producing areas, and its five well-defined spore stages have been described.

Overall, rust spores represent one of the least frequent spore types in the atmosphere of several regions, a feature also observed in Madeira (Table 2). Mean annual concentrations of 6 spores $\mathrm{m}^{-3}$ were recorded in Mexico City, with the largest concentrations towards the end of the wet season and the beginning of the dry season (Calderon et al. 1995). Average monthly concentrations below 17 spores $\mathrm{m}^{-3}$ were obtained in Mérida, SW Spain (Trejo et al. 2013). In addition, a survey performed in Cartagena, SE Spain, Puccinia spores attained $0.94 \%$ of total spores, revealing maximum daily counts of 149 spores $\mathrm{m}^{-3}$ (Elvira-Rendueles et al. 2013). Guarín et al. (2015) reported 137.6 spores $\mathrm{m}^{-3}$ in the atmosphere of Medellin, Colombia, during February and March of 2011. In our survey, a marked increase of total spores is noticeable between 2007 and 2010 and from 2011 to 2012 (Table 3). Several factors might explain this trend, namely an increase of human introduction of seeds and infected plants, vectors (e.g. insects and birds) and wind dispersal (Nagarajan and Singh 1990). The trade winds that blow at subtropical latitudes provide frequent opportunities for trans-Atlantic ocean movement of spores from places like Morocco/Spain to the Western hemisphere (Isard and Russo 2011). Considering the proximity of Madeira to the African coast and the number of dust outbreaks reported over the North Atlantic in the last decades, the archipelago intersects westward transport route dust plumes (Goudie and Middleton 2001). Such events can deposit inorganic matter and microorganisms such as rusts fungi in downwind ecosystems (Herut et al. 2002; Vodonos et al. 2014), capable to produce countless amounts of urediniospores which are effective in long distance dissemination (Huerta-Espino et al. 2014).

The onset of Puccinia pathogenesis is ruled by some meteorological parameters, such as temperature and relative humidity, which in turn influence the airborne dispersion of the spores. The fluctuations of Puccina spores in the atmosphere of Madeira during the studied period showed a higher dependence on relative humidity and a significant negative correlation with rainfall (Table 4). Magyar and Manninger (2004) found that counts of Puccina spp. correlated positively with temperature, whereas high humidity, number of rainy days, and duration of precipitation had a negative effect on the spore concentration. In the case of wheat strip rust caused by P. striiformis, temperature (Ma et al. 2017), moisture and wind are the most important weather factors affecting epidemics (Luck et al. 2011).

Essentially, rust diseases are strongly affected by moisture, temperature and wind (Luck et al. 2011). The initiation of rust epidemics depends on all the above parameters but critically on rainfall as a source of primary inoculum that effectively deposits spores travelling long distances (Nagarajan and Singh 1990). In fact, rainfall plays an important role in various features of the biology of rust fungi and ultimately in their life history (Morris et al. 2013).

In a simulation study performed by Geagea et al. (1999), it was shown the relevance of rain type in the removal of brown (Puccinia recondite f.sp. tritici) and yellow (P. striiformis) rust spores. For both rusts, the number of both dry-dispersed and rain-splashed spores, as well as their travel distance, increased with drop diameter and fall height.

In turn, disease outbreaks of $P$. psidii on Syzygium jambos in Brazil were linked to duration of leaf wetness and relative humidity combined with optimal nocturnal temperatures between $18{ }^{\circ} \mathrm{C}$ and $22^{\circ} \mathrm{C}$ (Tessmanna et al. 2001). In the host Eucalyptus grandis the invasion of $P$. psidii was related with days with $90 \%$ relative humidity or higher for $8 \mathrm{~h}$, combined with temperatures ranging from $18{ }^{\circ} \mathrm{C}$ to $25^{\circ} \mathrm{C}$ (Glen et al. 2007). It has been pointed out that airborne urediniospores showed maximum concentration when relative humidity reaches 75-85\% and when temperatures attain $29-31^{\circ} \mathrm{C}$. Other evidence revealed that the aeciospores of Puccinia sp. were expelled with a discharge mechanism depending directly on humidity (Mallaiah and Rao 1982).

The influence of the temperature in particular has been studied on several rust species, as in the case of stripe rust infection caused by $P$. striiformis f.sp. tritici. There is evidence that increasing global temperatures may limit the development and survival of Puccinia in some wheat growing regions around the world. Some reports showed that the prevalence of this species decreased with increases in average annual temperature, and the epidemics frequency and severity increases were associated with increased winter temperatures and lower spring temperatures (Luck et al. 2011). During the tenyear period, air temperature and relative humidity correlated either positively or negatively with rust spores in Madeira Island, this even though the negative influence of temperature was noticeable on most of the studied years (6 years) (Table 4). According to Luck et al. (2011) 
such a pattern can represent a decrease in rust epidemics frequency and severity in a region. In fact, we reported low levels of airborne rust spore concentrations in Madeira over the years. However, we considered it important to include more years of airborne spore sampling in order to clarify the correlation between meteorological parameters, in particularly the average temperature and the occurrence of rust spores. On the contrary, Trejo et al. (2013) found a positive correlation with temperature and Puccinia spore occurrence while relative humidity revealed a negative influence. Furthermore, Magyar and Manninger (2004) observed that Puccinia uredospore counts were increased not only by temperature but also evaporation and solar radiation. These authors also found that high relative humidity, cloud cover and precipitation reduced uredospore counts.

According to Trejo et al. (2013), the wind showed a significant positive and/or negative influence depending on the wind direction, a feature also observed in our survey. In the experiments of Smith (1966) it was observed that there was a higher production of Puccinia spores under increased wind speed conditions, a feature also stated by Magyar and Manninger (2004). In our survey, Puccinia spores presented positive correlation with wind speed in 2004 and 2005 but did not present significant correlation coefficients in the remaining years.

Similarly, the findings previously reported by Hermansen et al. (1978) noted that fast moving winds generally release more urediniospores than slow winds. As urediniospores are aerodynamically ultra-light and produced in unquantified quantities, they can be spread by wind and convection currents assuring long distance dissemination (Morin et al. 2012; Morris et al. 2013). Ultimately, future analysis of weather and aeromycological data along with ground surveys and remote sensing shall provide a better understanding of what may increase rust spores, their provenance and source features. The combined techniques can help clarify the dispersal mechanisms, seasonal patterns and anticipate eminent threats of such invasive fungi.

In conclusion, there are several biological and environmental requirements that turn Puccinia spp. into an important plant pathogen. However, considering the low infection frequencies and the levels of airborne spore concentrations, rusts do not represent important plant pathogens in Madeira Island.
Acknowledgements The authors are grateful to the Portuguese Society of Allergology and Clinical Immunology (SPAIC) for the help and support in the aerobiological study and the Institute of Ocean and Atmosphere (IPMA) - Regional Station in Funchal for providing the meteorological data. Special thanks go to the Center for Invasive Species and Ecosystem Health, USA, for providing selected images of rust species.

\section{Compliance with ethical standards}

Conflict of interest The authors declare that they have no conflict of interest.

\section{References}

Agrios, G. N. (1997). Plant pathology. San Diego: Academic press.

Babadoost, M. (1991). Common rust and southern rust of sweet corn. Report on plant disease. University of Illinois Extension, RPD, (Serial No. 965).

Bonde, M. R., Palmer, C. L., Luster, D. G., Nester, S. E., Revell, J. M., \& Berner, D. K. (2014). Viability of Puccinia horiana teliospores under various environmental conditions. Plant Health Progress, 15, 25-28. https://doi.org/10.1094/PHPRS-13-0117.

Borges, P. A. V., Abreu, C., Aguiar, A. M. F., Carvalho, P., Jardim, R., Melo, I., et al. (2008). A list of the terrestrial fungi, flora and fauna of Madeira and Selvagens archipelagos. Direcção Regional do Ambiente da Madeira and Universidade dos Açores, Funchal and Angra do Heroísmo.

Calderon, C., Lacey, J., McCartney, H. A., \& Rosas, I. (1995). Seasonal and diurnal variation of airborne basidiomycete spore concentrations in Mexico City. Grana, 34, 260-268.

Calheta (Madeira) (2017). https://www.infopedia.pt/\$calheta(madeira). Accessed 5 Jan 2017.

D'Amato, G., \& Spieksma, F. Th. M. (1995). Aerobiologic and clinical aspects of mould allergy in Europe. European Academy of Allergology and Clinical Immunology Position Paper. Allergy, 50, 870-877.

De Backer, M., Alaei, H., Van Bockstaele, E., Roldan-Ruiz, I., van der Lee, T., Maes, M., et al. (2011). Identification and characterization of pathotypes in Puccinia horiana, a rust pathogen of Chrysanthemum x morifolium. European Journal of Plant Pathology, 130, 325-338.

De Wolf, E., Murray, T., Paul, P., Osborne, L., \& Tenuta, A. (2011). Identification and Management of Stem Rust on Wheat and Barley. USDA-CREES Extension IPM 2009-41533-05331. http://plantpath.wsu.edu/wp-content/uploads/2012/10/StemRust-Man-WA1.pdf. Accessed 15 Nov 2016.

Dennis, R. W. G. (1986). Fungi of the Hebrides. Kew: Royal Botanic Garden.

Dunhin, B. J., Pretorius, Z. A., Bender, C. M., Kloppers, F. J., \& Flett, B. C. (2004). Description of spore stages of Puccinia sorghi in South Africa, south African. Journal of Plant Soil, $21,48-52$. 
Elvira-Rendueles, B., Moreno, J., Garcia-Sanchez, A., Vergara, N., Martinez-Garcia, M. J., \& Moreno-Grau, S. (2013). Airspore in Cartagena, Spain: Viable and non-viable sampling methods. Annals of Agricultural and Environmental Medicine, 20, 664-671.

EPPO/CABI. (1997). Puccinia horiana. In I. M. Smith, D. G. McNamara, P. R. Scott, \& M. Holderness (Eds.), Quarantine pests for Europe. Wallingford: CABI.

Farr, D. F., Bills, G. F., Chamuris, G. P., \& Rossman, A. Y. (1989). Fungi on plants and plant products in the United States. St. Paul: American Phytopathological Society Press.

Fried, G., Chauvel, B., Reynaud, P., \& Sache, I. (2017). Decreases in crop production by non-native weeds, pests, and pathogens. In M. Vilá \& P. E. Hulme (Eds.), Impact of biological invasions on ecosystem services (pp. 83-102). Switzerland: Springer International Publishing.

Gage, S. H., Isard, S. A., \& Colunga-Garcia, M. (1999). Ecological scaling of aerobiological dispersal processes. Agricultural and Forest Meteorology, 97, 249-261.

Galán, C., Cariñanos, P., Alcázar, P., \& Dominguez-Vilches, E. (2007). Spanish aerobiology network (REA) management and quality manual. Córdoba: Servicio de Publicaciones Universidad de Córdoba, Argos Impresores SL.

Galán, C., Smith, M., Thibaudon, M., Frenguelli, G., Oteros, J., Gehrig, R., et al. (2014). Pollen monitoring: Minimum requirements and reproducibility of analysis. Aerobiologia, 30, 385-395.

Geagea, L., Hubera, L., \& Sache, I. (1999). Dry-dispersal and rain-splash of brown (Puccinia recondite f.sp. tritici) and yellow (P. striiformis) rust spores from infected wheat leaves exposed to simulated raindrops. Plant Pathology, 48, 472-482.

Ghatge, M. M., Salunkhe, V. S., \& Jadhav, R. R. (2013). Diversity of airborne fungi in Kadegaon Tahsil, district Sangli, MS, India. International Research Journal of Environmental Sciences, 2, 26-29.

Gjaerum, H. B. (1982). Rust fungi from Madeira. Boletim do Museu Municipal do Funchal, 34, 1-22.

Glen, M., Alfenas, A. C., Zauza, E. A. V., Wingfield, M. J., \& Mohammed, C. (2007). Puccinia psidii: A threat to the Australian environment and economy-a review. Australasian Plant Pathology, 36, 1-16.

Göre, M. E. (2008). Geranium rust disease caused by Puccinia pelargonii-zonalis: First report in Turkey. Plant Pathology, 57, 786.

Goudie, A. S., \& Middleton, N. J. (2001). Saharan dust storms: Nature and consequences. Earth-Science Reviews, 56, 179204.

Gregorio-Cipriano, M. R., Fernández-Pavía, S. P., RodríguezAlvarado, G., \& Gómez-Dorantes, N. (2013). First report of geranium rust (Puccinia pelargonii-zonalis) in the state of Michoacán, México. Plant Disease, 97(12), 1660 http://apsjournals.apsnet.org/doi/abs/10.1094/PDIS-05-130570-PDN. Accessed 14 Nov 2016.

Guarín, F. A., Abril, M. A. Q., Alvarez, A., \& Fonnegra, R. (2015). Atmospheric pollen and spore content in the urban area of the city of Medellin, Colombia. Hoehnea, 42, 9-19.

Harrison, J. M. (1987). Observations on the occurrence of telia of Puccinia porri on leeks in the UK. Plant Pathology, 36, 114-115.
Hermansen, J. E., Torp, U., \& Prahm, L. P. (1978). Studies of transport of live spores of cereal mildew and rust fungi across the North Sea. Grana, 17, 41-46.

Herut, B., Collier, R., \& Krom, M. D. (2002). The role of dust in supplying nitrogen and phosphorus to the Southeast Mediterranean. Limnology and Oceanography, 47(3), 870878.

Hiratsuka, Y., \& Sato, S. (1982). Morphology and taxonomy of rust fungi. In K. Scott \& A. K. Chakravorty (Eds.), The rust fungi (pp. 1-36). New York: Academic press.

Hirst, J. M. (1952). An automatic volumetric spore trap. Annals of Applied Biology, 39, 257-265.

Ho, T. M., Tan, B. H., Ismail, S., \& Bujang, M. K. (1995). Seasonal prevalence of air-borne pollen and spores in Kuala Lumpur, Malaysia. Asian Pacific Journal of Allergy and Immunology, 13, 17-22.

Holl, F. (1830). Verzeichniss der auf der Insel Madeira beobachteten Pflazen, nebst Beschreibung einiger neuen Arten. Flora, 13, 369-392.

Huerta-Espino, J., Singh, R. P., \& Roelfs, A. P. (2014). Rust fungi of wheat. In J. K. Misra, J. P. Tewari, S. K. Deshmukh, \& C. Vágvölgyi (Eds.), Fungi from different substrates (pp. 217259). Boca Raton: CRC press.

Hutchidon, L. J. (1996). Puccinia pelargonii-zonalis (Uredinales: Pucciniaceae), an addition to the rust flora of Canada. Mycoscience, 37, 467-469.

Isard, S. A., \& Russo, J. M. (2011). Risk assessment of aerial transport of rust pathogens to the western hemisphere and within North America. In McIntosh, R. (Ed.) Proc BGRI 2011Technical Workshop (pp. 25-34). St. Paul. http://www. globalrust.org/sites/default/files/2011\%20BGRI\%20 plenary\%20presentations-ALL.pdf. Accessed 18 May 2017.

Isard, S. A., Gage, S. H., Comtois, P., \& Russo, J. M. (2005). Principles of the atmospheric pathway for invasive species applied to soybean rust. Bioscience, 55, 851-861.

Jędryczka, M., Brachaczek, A., Kaczmarek, J., Dawidziuk, A., Kasprzyk, J., Mączyńska, A., et al. (2012). System for forecasting disease epidemics (SPEC) - Decision support system in polish agriculture, based on aerobiology. Alergologia Immunologia, 9, 89-91.

Kadam, R. M., Reddy, N. J. M., \& Biradar, R. P. (2010). Air-borne spore population of Puccinia penniseti in relation to rust disease of bajra at Ahmedpur. International Journal of Plant Protection, 3, 160-162.

Kolmer, J. A. (2001). Early research on the genetics of Puccinia Graminis and stem rust resistance in wheat in Canada and the United States. In P. D. Peterson (Ed.), Stem rust of wheat: From ancient enemy to modern foe (pp. 51-82). St Paul: APS press.

Levetin, E., \& Horner, W. E. (2002). Fungal aerobiology: Exposure and measurement. Chemical Immunology, 81, 10-27.

Luck, J., Spackman, M., Freeman, A., Trebicki, P., Griffiths, W., Finlay, K., et al. (2011). Climate change and diseases of food crops. Plant Pathology, 60, 113-121.

Ma, L., Hu, X., \& Xu, X. (2017). Effect of controlled fluctuating low temperatures on survival of Puccinia striiformis $\mathrm{f}$. sp. Tritici. European Journal of Plant Pathology, 147, 713-716.

Magyar, D., \& Manninger, K. (2004). Effects of meteorological conditions on uredo- and teliospores of rusts. In Proceedings of the International Cereal Rusts and 
Powdery Mildews Conference. Norwich: John Innes Centre, 22-27 August 2004.

Mallaiah, K. V., \& Rao, A. S. (1982). Aerial dissemination of urediniospores of groundnut rust. Transactions of the British Mycological Society, 78, 21-28.

Marasas, C. N., Smale, M., \& Singh, R. P. (2004). The economic impact in developing countries of leaf rust resistance breeding in CIMMYT-related spring bread wheat. Economics program paper 04-01. Mexico: D. F, CIMMYT.

Morin, L., Aveyard, R., Lidbetter, J. R., \& Wilson, P. G. (2012). Investigating the host-range of the rust fungus Puccinia psidii sensu lato across tribes of the family Myrtaceae present in Australia. PloS One, 7, e35434.

Morris, C. E., Sands, D. C., Glaux, C., Samsatly, J., Asaad, S., Moukahel, A. R., et al. (2013). Urediospores of rust fungi are ice nucleation active at $>-10{ }^{\circ} \mathrm{C}$ and harbor ice nucleation active bacteria. Atmospheric Chemistry and Physics, 13, 4223-4233.

Nagarajan, S., \& Singh, D. V. (1990). Long-distance dispersion of rust pathogens. Annual Review of Phytopathology, $28,139-153$.

Pegg, G. S., Giblin, F. R., McTaggart, A. R., Guymer, G. P., Taylor, H., Ireland, K. B., et al. (2014). Puccinia psidii in Queensland, Australia: Disease symptoms, distribution and impact. Plant Pathology, 63, 1005-1021.

Peixoto-Junior, R. F., Creste, S., Landell, M. G. A., Nunes, D. S., Sanguino, A., Campos, M. F., et al. (2014). Genetic diversity among Puccinia Melanocephala isolates from Brazil assessed using simple sequence repeat markers. Genetics and Molecular Research, 13, 7852-7863.

Preece, T. F. (2000). The strange story of the box rust, Puccinia buxi, in Britain. Mycologist, 14(part 3), 104-106.

Pria, M. D., Zagonel, J., \& Fernandes, E. C. (2008). Controle de ferrugem na cultura do alho com uma nova mistura de fungicidas. Horticultura Brasileira, 26, 268-270.

Purdy, L. H., Krupa, S. V., \& Dean, J. L. (1985). Introduction of sugarcane rust into the Americas and its spread to Florida. Plant Disease, 69, 689-693.

Quintal, R. (2007). Quintas, Parques e Jardins do Funchal - Estudo fitogeográfico. Lisboa: Esfera do Caos Editores.

RHS. (2016). Box problems, Diseases of box. https://www.rhs. org.uk/advice/profile?PID=851. Accessed 2 Nov 2016.

Rivas-Martínez, S. (2001). Bioclimatic map of Europe Thermotypes. Léon: University of Léon, Cartographic Service.

Rivera-Mariani, F. E., \& Bolanños-Rosero, B. (2012). Allergenicity of airborne basidiospores and ascospores: Need for further studies. Aerobiologia, 28, 83-97.

Roelfs, A. P. (1985). Epidemiology in North America. In A. P. Roelfs \& W. R. Bushnell (Eds.), The cereal rusts, diseases, distribution epidemiology and control (pp. 403-434). Orlando: Academic Press.

Russi, L., Romani, M., \& Pecetti, L. (2009). Susceptibility to rust (Puccinia sp.) in cultivars of Italian and perennial ryegrass grown in two locations of Italy. Italian Journal of Agronomy, 1, 69-77.

Sadyś, M., Adams-Groom, B., Herbert, R. J., \& Kennedy, R. (2016). Comparisons of fungal spore distributions using air sampling at Worcester, England (2006-2010). Aerobiologia. https://doi.org/10.1007/s10453-016-9436-4.

Sansford, C., Beal, E. J., Denton, G., \& Denton, J. O. (2015). First report of the rust Puccinia porri on cultivated Allium vineale 'Hair'. New Disease Reports, 31, 4. https://doi.org/10.5197 /j.2044-0588.2015.031.004.

Scocco, E. A., Walcott, R. R., Jeffers, S. N., \& Buck, J. W. (2013). Detection of Puccinia pelargonii-zonalis-infected geranium tissues and Urediniospores. Journal of Phytopathology, 161, 341-347.

Silva, E., Carvalho, R., Nunes, N., Ramos, A. P., \& Talhinhas, P. (2016). First report of Puccinia hemerocallidis causing daylily rust in Europe. Plant Disease, 100, 2163. https://oi. org/10.1094/PDIS-02-16-0242-PDN.

Smith, R. S. (1966). The liberation of cereal stem rust uredospores under various environmental conditions in a wind tunnel. Transactions of the British Mycological Society, 49, 33-41.

Talhinhas, P., Silva, E., Nunes, N., \& Ramos, A. P. (2016). First report of Puccinia thaliae causing rust on canna spp. in Europe. Plant Disease, 100(6), 1242. https://doi. org/10.1094/PDIS-12-15-1404-PDN.

Tessmanna, D. J., Dianeseb, J. C., Miranda, A. C., \& Castro, L. H. R. (2001). Epidemiology of a Neotropical rust (Puccinia psidii): Periodical analysis of the temporal progress in a perennial host (Syzygium Jambos). Plant Patholology, 50, 725-731.

Trejo, F. H., Rodríguez, A. F. M., Molina, F. T., \& Palacios, I. S. (2013). Airborne spores of basidiomycetes in Mérida (SW Spain). Annals of Agriculture Environment Medicine, 20, 657-663.

Vodonos, A., Friger, M., Katra, I., Avnon, L., Krasnov, H., Koutrakis, P., et al. (2014). The impact of desert dust exposures on hospitalizations due to exacerbation of chronic obstructive pulmonary disease. Air Quality, Atmosphere and Health. https://doi.org/10.1007/s11869-014-0253-z.

Zadoks, J. C. (1967). International dispersal of fungi. Netherlands Journal of Plant Pathology, Supp. 1, 61-80.

Zanatta, P. (2013). Controle preventivo de doenças foliares em híbridos comerciais de milho com fungicidas em espaçamento reduzido. Master's thesis, Brazil: Universidade Estadual do Centro-Oeste, Unicentro. 